\title{
Piperlongumine inhibits gastric cancer cells via suppression of the JAK1,2/STAT3 signaling pathway
}

\author{
BAOJI SONG ${ }^{1 *}$, HONGJIE ZHAN $^{2 *}$, QUAN BIAN $^{1}$ and JUNPING GU ${ }^{1}$ \\ ${ }^{1}$ Department of General Surgery, Tianjin Hospital, Tianjin 300211; ${ }^{2}$ Department of Gastric Cancer, Tianjin Cancer Hospital, \\ Key Laboratory of Cancer Prevention and Treatment of Tianjin, Tianjin Medical University, Tianjin 300060, P.R. China
}

Received May 13, 2015; Accepted March 21, 2016

DOI: $10.3892 / \mathrm{mmr} .2016 .5091$

\begin{abstract}
Piperlongumine (PL), a major active component of long peppers, has been reported to possess anti-cancer properties; however, its effect on gastric cancer (GC) has remained to be demonstrated. The present study assessed the effects of PL on the MKN45 and AGS GC cell lines and explored the underlying mechanisms. An MTT assay revealed that PL suppressed the proliferation of GC cells, while flow cytometric analysis showed that PL inhibited cell cycle progression. Furthermore, Transwell assays revealed the inhibitory effects of PL on the invasion and migration of GC cells. In addition, PL reduced the phosphorylation of Janus kinase (JAK)1, JAK2 and signal transducer and activator of transcription (STAT) 3 in a concentration-dependent manner, as indicated by western blot analysis, and decreased the expression of STAT3-dependent tumor-associated genes in GC cells, as revealed by PCR analysis. In conclusion, the present study was the first, to the best of our knowledge, to reveal the efficacy of PL against GC. The consumption of long peppers is therefore recommended for the prevention and treatment of GC, and PL may be a promising candidate drug for treating GC.
\end{abstract}

\section{Introduction}

Gastric cancer (GC), one of the most common gastrointestinal malignancies in the world, accounts for $\sim 8 \%$ of all cancers (1) and is the second leading cause of cancer-associated mortality (2). Highest incidence rates are in Eastern Asia, Eastern Europe and South America, and lowest incidence rates are in North America and the majority of Africa (1). The

Correspondence to: Dr Quan Bian or Dr Junping Gu, Department of General Surgery, Tianjin Hospital, 406 Jiefangnan Road, Hexi, Tianjin 300211, P.R. China

E-mail: quan_bian@163.com

E-mail: gu_junping@163.com

${ }^{*}$ Contributed equally

Key words: piperlongumine, gastric cancer, proliferation, invasion, JAK1,2/STAT3 genesis and progression of GC are multi-step and multi-stage processes. In spite of the treatments available for GC, including surgery, radiotherapy, chemotherapy and gene therapy (3-8), the outcome is dismal due to relapses originating from the residual nidus being common. To improve the outcome for patients with GC and enhance the efficacy of GC treatments, novel drugs are urgently required.

Piperlongumine (PL), a primary constituent of long peppers, is a natural alkaloid found in the fruit as well as the roots of the plant (9). PL has broad biological activities, including bactericidal and insecticidal capabilities (10). Furthermore, it exhibits anti-atherosclerotic, anti-inflammatory, anti-platelet, cardioprotective, anti-depressant and analgesic effects (11-17). Of note, accumulating evidence has shown that PL has anti-cancer properties. For example, Randhawa et al (18) reported that PL could suppress the proliferation of colon cancer cells in a concentration- and time-dependent manner through the mitogen-activated protein kinase kinase/extracellular signal-regulated kinase pathway. Furthermore, Dhillon et al (19) demonstrated that PL inhibited the proliferation of pancreatic cancer cells by upregulating the levels or reactive oxygen species, which caused DNA damage. In addition, PL was reported to have anti-proliferative and apoptosis-inducing effects on human ovarian cancer cells (20).

However, to the best of our knowledge, the effects of PL on GC cells have not been demonstrated to date. Therefore, the present study evaluated the effects of PL on the MKN45 and AGS GC cell lines and explored the underlying mechanisms. The results demonstrated that PL inhibited the proliferation, cell cycle progression as well as cell invasion and migration of GC cells through suppression of the Janus kinase (JAK)1,2/signal transducer and activator of transcription (STAT)3 signaling pathway.

\section{Materials and methods}

Cell lines and reagents. The MKN45 and AGS human GC cell lines were purchased from the American Type Culture Collection (Manassas, VA, USA). All cells were cultured in RPMI 1640 medium (Hyclone, Logan, UT, USA) supplemented with $10 \%$ fetal bovine serum (FBS; Biowest, Nuaillé, France) in a humidified atmosphere containing $5 \% \mathrm{CO}_{2}$ at $37^{\circ} \mathrm{C}$. PL was purchased from Sigma-Aldrich (St. Louis, MO, USA). 
Cell proliferation assay. Cell proliferation was measured using a 3-(4,5-dimethylthiazol-2-yl)-2,5-diphenyltetrazolium bromide (MTT) assay. In brief, MKN45 and AGS cells were seeded into 96 -well plates at a density of $1 \times 10^{4}$ cells/well and cultured for $24 \mathrm{~h}$. The cells were then treated with various concentrations of PL $(0,10,20$ or $40 \mu \mathrm{M})$ for $24,48,72$ or 96 h. Subsequently, $20 \mu 1$ MTT solution (Sigma-Aldrich) was added to each well, followed by incubation at $37^{\circ} \mathrm{C}$ for $4 \mathrm{~h}$. The medium was carefully removed and $100 \mu$ ldimethyl sulfoxide (Sigma-Aldrich) was added into each well. The absorbance at $490 \mathrm{~nm}$ was determined using a spectrophotometer (GENESYS ${ }^{\mathrm{TM}}$ 20; Thermo Fisher Scientific, Inc., Waltham, MA, USA). Each experiment was performed at least three times.

Cell cycle assay. After treatment for $24 \mathrm{~h}$ with PL $(0,10,20$ or $40 \mu \mathrm{M}$ ), the cells were trypsinized and fixed overnight in $70 \%$ ethanol (Sigma-Aldrich) at $-20^{\circ} \mathrm{C}$. Next, the cells were collected and re-suspended in staining solution containing $50 \mathrm{mg} / 1$ propidium iodide (Sigma-Aldrich) and $100 \mathrm{mg} / \mathrm{l}$ RNase A (Sigma-Aldrich), followed by incubation in the dark for $30 \mathrm{~min}$ at room temperature. The cell cycle distribution was then analyzed with a flow cytometer (BD FACSAria II; BD Biosciences, Franklin Lakes, NJ, USA).

Cell invasion and migration assays. The invasive and migratory capacity of GC cells was detected using 24-well Transwell chambers (containing filters with $8-\mu \mathrm{m}$ pore size; Corning, Inc., Corning, NY, USA) according to the manufacturer's instructions. For the invasion assay, the insert membrane was coated with Matrigel (Invitrogen; Thermo Fisher Scientific, Inc.), while it was kept in its original condition for the migration assay. MKN45 or AGS cells $\left(1 \times 10^{5}\right)$ were seeded in the upper chambers and cultured in serum-free medium containing PL $(0,10,20$ or $40 \mu \mathrm{M})$ for $24 \mathrm{~h}$. Culture medium containing $10 \%$ FBS was added to the lower chamber. After $24 \mathrm{~h}$ of incubation at $37^{\circ} \mathrm{C}$, the cells on the upper surface of the membrane were scraped off with cotton swabs, while the cells on the lower surface of the membrane were fixed with methanol (Sigma-Aldrich) and stained with $0.1 \%$ crystal violet (Sigma-Aldrich), followed by counting under a microscope (CX22; Olympus Corporation, Tokyo, Japan). At least three independent experiments were conducted.

Western blot analysis. MKN45 cells were treated with $0,10,20$ and $40 \mu \mathrm{M}$ PL for $24 \mathrm{~h}$ and then lysed at $4^{\circ} \mathrm{C}$ for $20 \mathrm{~min}$ in radioimmunoprecipitation assay buffer (Sigma-Aldrich) containing 1\% Nonidet P40, 0.1\% sodium dodecyl sulfate (SDS), $0.5 \%$ sodium deoxycholate, $1 \mu \mathrm{M}$ sodium orthovanadate, $0.03 \%$ aprotinin and $10 \mathrm{ng} / \mathrm{ml}$ phenylmethylsulfonyl fluoride. The total protein was separated by $10 \%$ SDS-polyacrylamide gel electrophoresis (Bio-Rad Laboratories, Hercules, CA, USA) and then transferred onto a polyvinylidene difluoride membrane (Pierce Biotechnology, Inc., Rockford, IL, USA). The membranes were blocked with 5\% non-fat milk in Tris-buffered saline containing Tween 20 (TBST; Invitrogen; Thermo Fisher Scientific, Inc.) at room temperature for $1 \mathrm{~h}$ prior to incubation with the primary antibodies as follows: Rabbit polyclonal anti-JAK1 (1:1,500; Cell Signaling Technology, Inc., Danvers, MA, USA; cat.

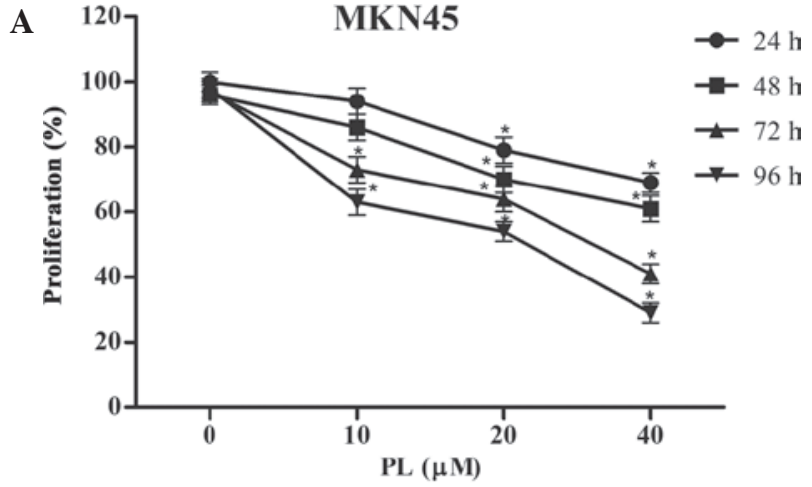

B

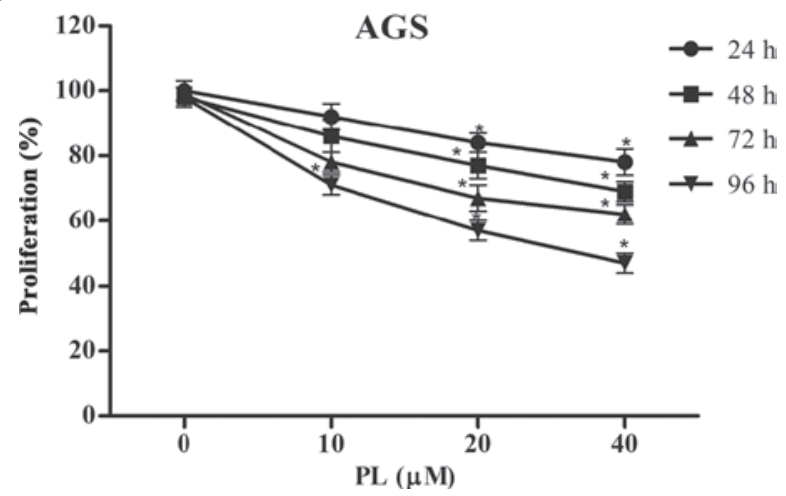

Figure 1. PL suppresses the proliferation of gastric cancer cells (A) MKN45 and (B) AGS cells were treated with 10,20 or $40 \mu \mathrm{M}$ of PL for $24,48,72$ or $96 \mathrm{~h}$ and cell proliferation was quantified using the MTT assay. Values are expressed as the mean \pm standard deviation of the percentage of the control group from three individual experiments. " $\mathrm{P}<0.05$ compared with the control group. PL, piperlongumine.

no. 3332); rabbit polyclonal anti-phosphorylated (p)-JAK1 (1:1,500; Cell Signaling Technology, Inc.; cat. no. 3331); rabbit polyclonal anti-JAK2 (1:1,500; Cell Signaling Technology, Inc.; cat. no. 3773); rabbit polyclonal anti-p-JAK2 (1:1,500; Cell Signaling Technology, Inc.; cat. no. 3774); mouse monoclonal anti-STAT3 (1:1,500; Cell Signaling Technology, Inc.; cat. no. 9139), mouse monoclonal anti-p-STAT3 (1:1,500; Cell Signaling Technology, Inc.; cat. no. 9138); and mouse monoclonal anti-glyceraldehyde-3-phosphate dehydrogenase (Santa Cruz Biotechnology, Inc., Dallas, TX, USA) at $4^{\circ} \mathrm{C}$ overnight. Following washing with TBST for $10 \mathrm{~min}$, the membranes were incubated for $1 \mathrm{~h}$ at room temperature in goat anti-mouse horseradish peroxidase-conjugated $(1: 3,000$; Santa Cruz Biotechnology, Inc.; cat. no. sc-2302) and rabbit anti-mouse horseradish peroxidase-conjugated secondary antibody (1:2,000; Santa Cruz Biotechnology, Inc.; cat. no. sc-358920) and then washed with TBST three times. The protein bands were visualized using a Pierce ECL Western Blotting kit (Thermo Fisher Scientific, Inc.). The absorbance values of target proteins were analyzed with Gel-Pro Analyzer software (version 4.0; Media Cybernetics, Inc., Rockville, MD, USA).

Reverse-transcription quantitative polymerase chain reaction ( $R T-q P C R)$ analysis. The total RNA was isolated from the PL-treated MKN45 cells with TRIzol reagent (Invitrogen) in accordance with the manufacturer's instructions and then transcribed into complementary DNA using a PrimeScript RT reagent kit (Takara Bio Inc., Otsu, Japan). 

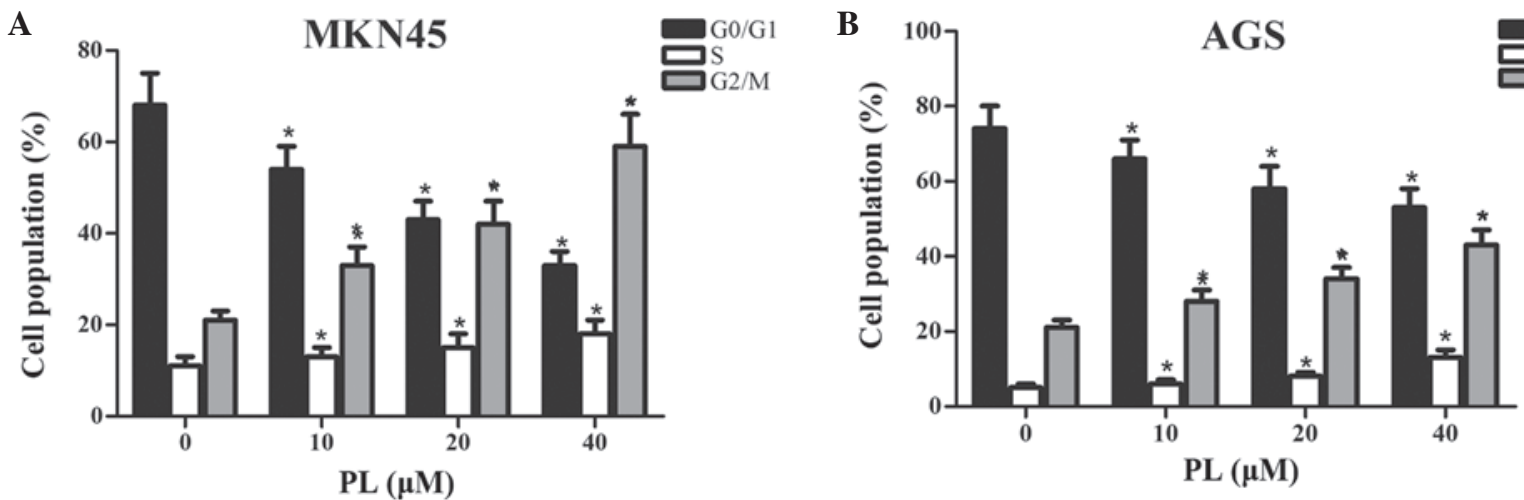

Figure 2. PL induces cell cycle arrest in gastric cancer cells. Flow cytometry was applied to analyze the cell cycle distribution of (A) MKN45 and (B) AGS cells treated with different concentrations of PL for $24 \mathrm{~h}$. Values are expressed as the mean \pm standard deviation of the percentage from three individual experiments. ${ }^{*} \mathrm{P}<0.05$ compared with the control group. PL, piperlongumine.
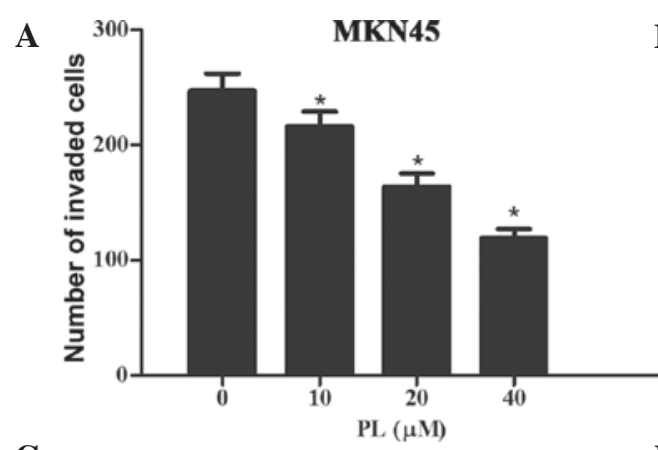

C

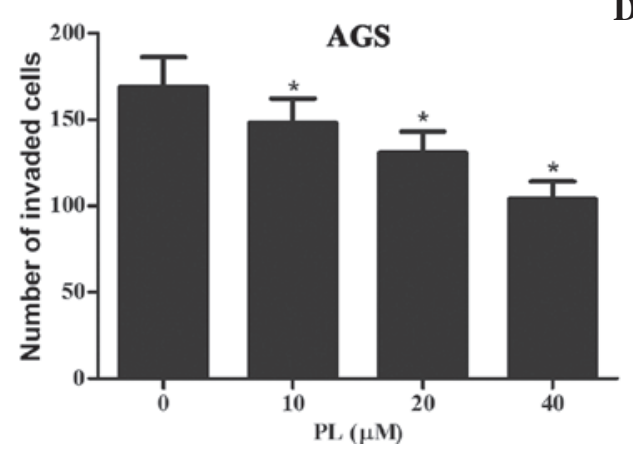

B
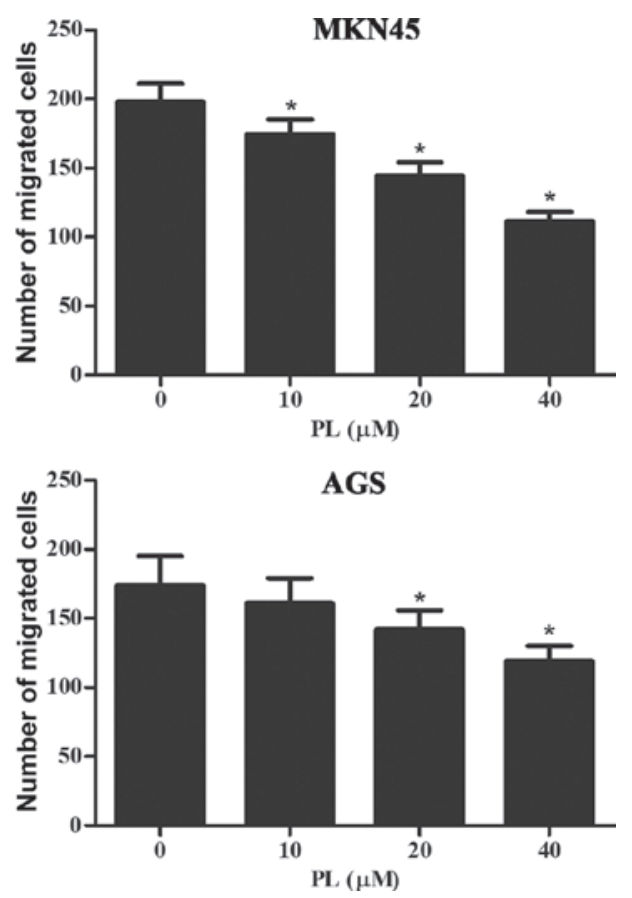

Figure 3. PL suppresses the invasion and migration of gastric cancer cells. Cells were treated with $0,10,20$ or $40 \mu \mathrm{M}$ PL for $24 \mathrm{~h}$, followed by assessment of invasion and migration using Transwell chambers. In MKN45 cells treated with PL, the amount of cells (A) invading and (B) migrating through the membrane was decreased. In AGS cells treated with PL, the amount of cells (C) invading and (D) migrating through the membrane was also decreased. Values are expressed as the mean \pm standard deviation of number of cells per four high power microscope fields with all experiments repeated at least three times. $\mathrm{P}<0.05$ compared with the control group. PL, piperlongumine.

Primers for gene amplification were from Invitrogen (Ki-67, cat. no. Mm01278617_m1; Cyclin D1, cat. no. Mm00487804_ m1; MMP-9, cat. no. Mm00600163_m1; Twist, cat. no. Mm00442036_m1; Hprt1, cat. no. Mm00446968_m1). Hprt1 was used as the control. PCR amplification was performed in a 7300 RT-PCR System (Applied Biosystems; Thermo Fisher Scientific, Inc.) using the following conditions: Initial denaturation at $94^{\circ} \mathrm{C}$ for $3 \mathrm{~min}$; 40 cycles of denaturation at $94^{\circ} \mathrm{C}$ for $10 \mathrm{~min}$, annealing at $55^{\circ} \mathrm{C}$ for $30 \mathrm{sec}$ and extension at $72^{\circ} \mathrm{C}$ for $20 \mathrm{sec}$. Melt curve analysis was conducted from 65 to $95^{\circ} \mathrm{C}$. The mixture contained $5 \mu 1$ SsoFast EvaGreen Supermix (Bio-Rad Laboratories, Inc.), $1 \mu \mathrm{l}$ cDNA (diluted 1:50), and $2 \mu 1$ each forward and reverse primers $(1 \mu \mathrm{M})$ to a final volume of $20 \mu \mathrm{l}$. The experiment was performed at least three times. Relative expression values were calculated using the $2^{-\Delta \Delta \mathrm{Cq}}$ method as previously described (21).

Statistical analysis. All experiments were performed at least three times. Values are expressed as the mean \pm standard deviation. Differences between groups were compared using analysis of variance using SPSS 13.0 software (SPSS, Inc., Chicago, IL, USA). P $<0.05$ was considered to indicate a statistically significant difference between values.

\section{Results}

PL suppresses the proliferation of GC cells. The anti-proliferative effects of PL on GC cells were determined using an MTT assay. As shown in Fig. 1, PL significantly 

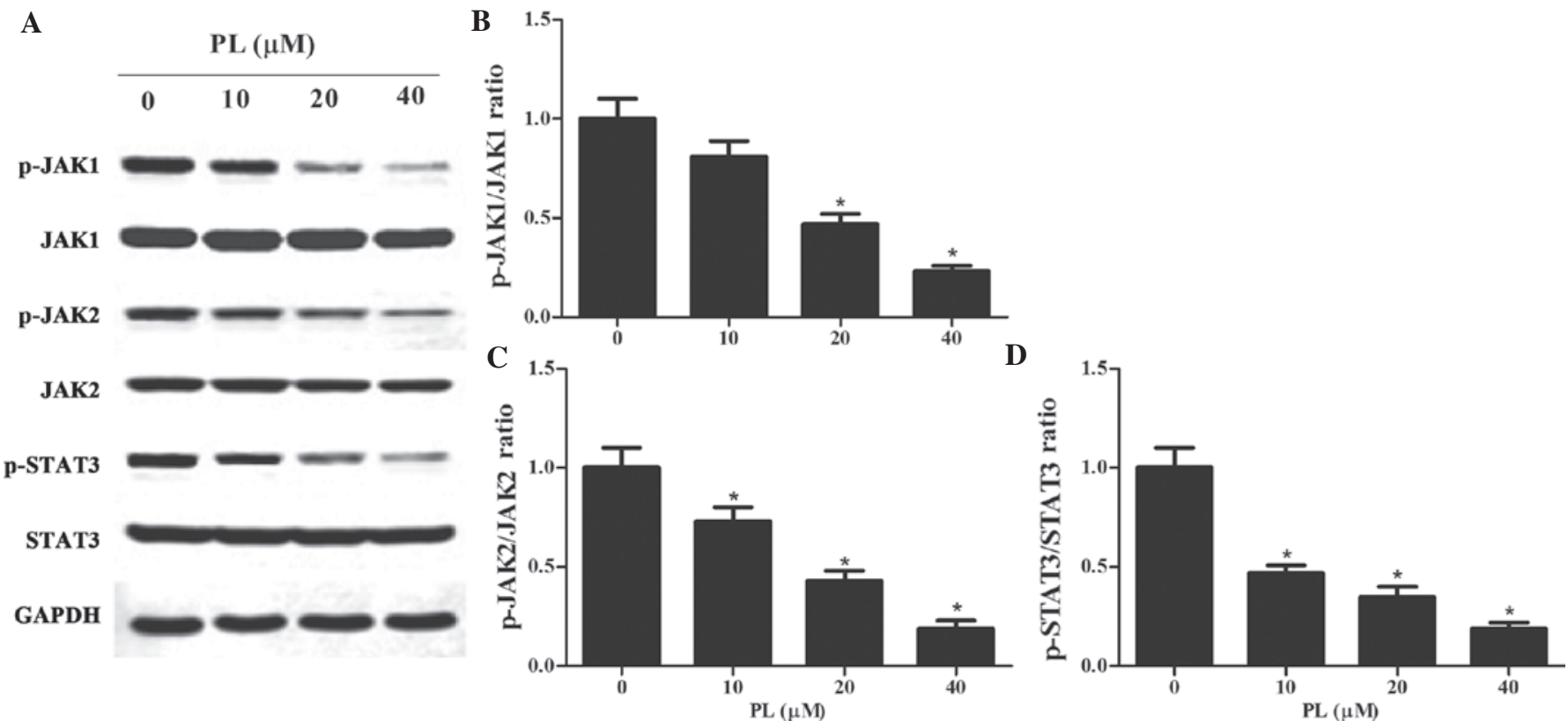

Figure 4. PL reduces STAT3 activity by downregulating JAK1/2 activity in gastric cancer cells. (A) Representative western blot of MKN45 cells treated with various concentrations of PL for $24 \mathrm{~h}$. GAPDH was used as a loading control. The protein expression levels of (B) p-JAK1/JAK1, (C) p-JAK2/JAK2 and (D) p-STAT3/STAT3 were determined by densitometric analysis of the bands. "P<0.05 compared with the control group. PL, piperlongumine; p-JAK, phosphorylated Janus kinase; STAT3, signal transducer and activator of transcription 3.

A

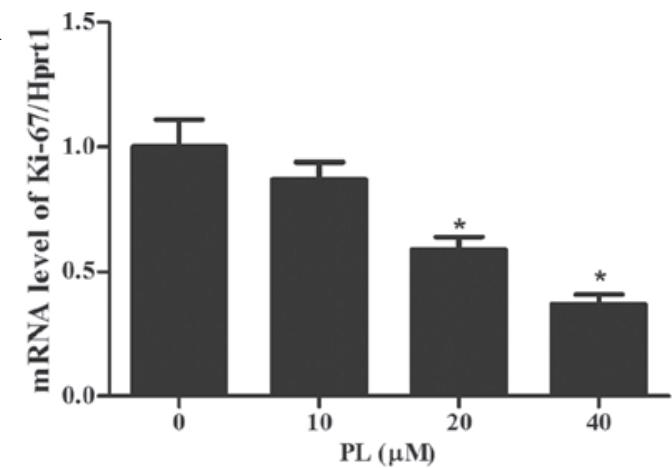

C

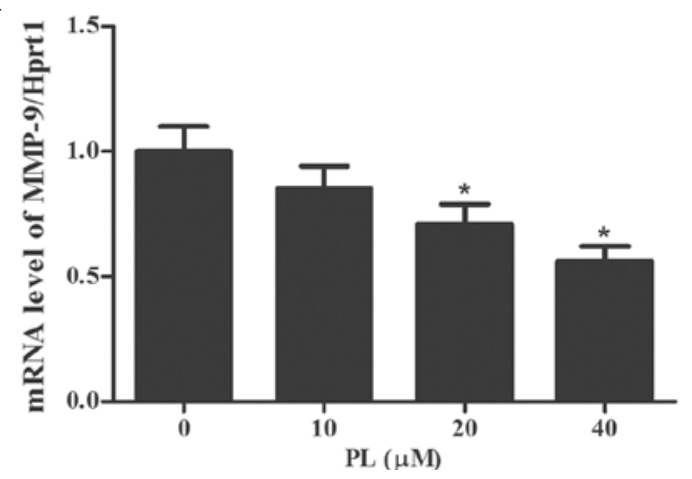

B

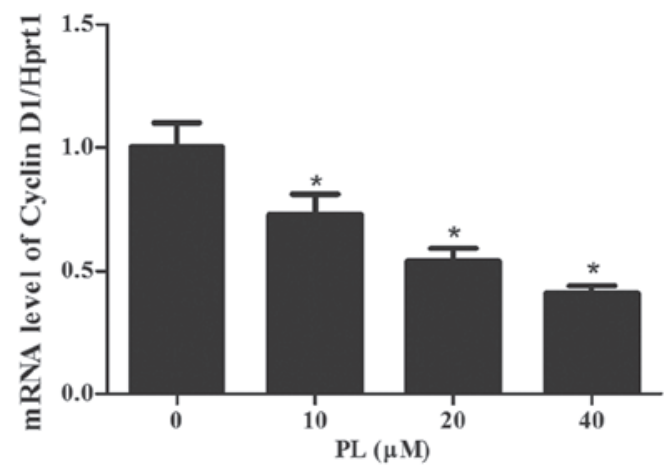

D

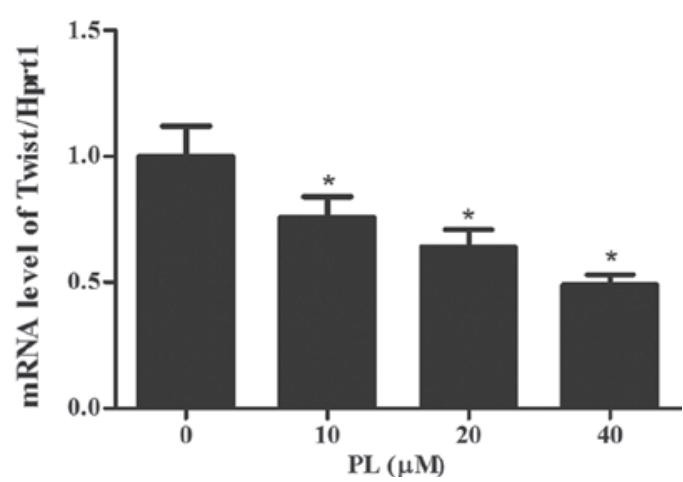

Figure 5. PL modulates the expression of STAT3-dependent tumor-associated genes. The mRNA expression levels of (A) Ki-67, (B) Cyclin D1, (C) MMP-9 and (D) Twist in MKN45 cells treated with $0,10,20$ or $40 \mu \mathrm{M}$ PL for $24 \mathrm{~h}$ were measured by reverse-transcription quantitative polymerase chain reaction analysis. Values are expressed as the mean \pm standard deviation. ${ }^{*} \mathrm{P}<0.05$ compared with the control group. PL, piperlongumine.

suppressed proliferation of MKN45 and AGS cells in a concentration- and time-dependent manner.

$P L$ induces cell cycle arrest in G2/M phase in GC cells. To investigate whether PL inhibited the proliferation of GC cells via interfering with cell cycle progression, MKN45 and AGS cells treated with PL for $24 \mathrm{~h}$ were subjected to flow cytometric cell cycle analysis. As shown in Fig. 2, an increase in the G2/M-phase population from 21 to 28,34 and 43, along with a decrease in G0/G1 phase from 74 to 66,58 and $53 \%$ was observed in MKN45 cells, after $24 \mathrm{~h}$ of treatment with PL at $0,10,20$ or $40 \mu \mathrm{M}$, respectively. Similarly, an increase in 
the G2/M-phase population from 21 to 33, 42 and 59\%, along with a decrease in $\mathrm{G} 0 / \mathrm{G} 1$ phase from 68 to 54,43 and $33 \%$ was found in AGS cells after $24 \mathrm{~h}$ of treatment with PL at 0, 10, 20 or $40 \mu \mathrm{M}$, respectively. Furthermore, slight dose-dependent increase in the number of MKN45 and AGS cells in S phase after treatment with PL was observed. All of these results suggested that PL dose-dependently induced G2/M-phase arrest in GC cells.

PL suppresses the invasion and migration of GC cells. Subsequently, the effects of PL on the invasion and migration of GC cells were assessed. Invasion of GC cells was assessed using Transwell chambers with Matrigel-coated membranes, while the membranes were kept in their original condition for the migration assay. As shown in Fig. 3A and B, PL dose-dependently inhibited the invasion and migration of MKN45 cells. Furthermore, the invasion and migration of AGS cells was also inhibited by PL in a concentration-dependent manner (Fig. 3C and D).

PL de-activates STAT3 activity by downregulating $J A K 1 / 2$ activity in GC cells. STAT3 has been reported to be constitutively activated in GC cells $(22,23)$. As activation of STAT3 is associated with the activation of upstream JAKs (24), the present study examined whether PL affected the JAK/STAT3 pathway. Western blot analysis was performed on lysates of PL-treated MKN45 cells, revealing that PL treatment downregulated p-JAK1, p-JAK2 and p-STAT3 in a concentration-dependent manner (Fig. 4). However, total protein expression of JAK1, JAK2 and STAT3 was not altered by PL treatment.

PL decreases the expression of STAT3-dependent tumor-associated genes. To investigate whether PL showed a specific effect on STAT3-regulated genes, MKN45 cells were treated with different concentrations of PL for $24 \mathrm{~h}$, followed by RT-qPCR analysis of the mRNA expression of the STAT3 target genes Ki-67 (a proliferation marker), Cyclin D1 (a cell cycle regulator), MMP-9 and Twist (associated with invasion) (25-27). As shown in Fig. 5, the mRNA expression levels of all of these genes were decreased by PL in a concentration-dependent manner. These results indicated that by inhibiting STAT3, PL interferes with the expression of these STAT3-dependent genes, which may be associated with its mechanism of action.

\section{Discussion}

At present, treatments for GC have limitations due to the occurrence of relapses. Therefore, it is urgently required to develop novel treatment modalities to improve the outcome of GC therapies. The present study demonstrated the inhibitory effects of PL on GC cells and assessed the underlying mechanisms. The results showed that PL suppressed the proliferation, cell cycle progression as well as invasion and migration of GC cells through inhibition of the JAK1,2/STAT3 signaling pathway.

JAKs, comprised of JAK1, JAK2, JAK3 and TYK2, belong to a family of non-receptor tyrosine kinases (28). They are phosphorylated by cytokine and growth factor receptor signaling, which then results in activation of STAT3 (3,29-31). STAT3, a member of the STAT family of transcription factors, exists in the cytoplasm and is tightly mediated under physiological conditions. Its activation, strictly controlled in normal tissues, contributes to tumorigenesis by driving biological processes and cellular functions, including proliferation, survival, metastasis, angiogenesis, immune evasion and inflammation (32-36). The JAK/STAT3 signaling pathway has been reported to have a central role in $\mathrm{GC}$ and is thus a common target of GC treatments (37,38). For example, Kim et al (39) demonstrated that OPB-31121 exhibited an antitumor effect on GC cells by disrupting the JAK2/STAT3 pathway. In addition, GC cell growth was reported to be reduced by suppression of the JAK2/STAT3 pathway $(38,40,41)$. Another previous study demonstrated that JAK1/STAT3 signaling is also involved in the invasion of cancer cells (42). The present study revealed that phosphorylation of JAK1, JAK2 and STAT3 was dose-dependently inhibited by PL in GC cells. This indicated that PL may exert its effects on GC cells by suppression of JAK1 and JAK2 activation, resulting in reduced STAT3 activation.

Subsequently, the effects of PL on the expression of target genes of STAT3 relevant to proliferation (Ki-67), cell cycle progression (Cyclin D1) and invasion (MMP-9 and Twist) were assessed. The results showed that PL treatment significantly and dose-dependently reduced the mRNA expression levels of all of these genes. The present study revealed that PL suppressed the proliferation of the MKN45 and AGS cells by inducing cell cycle arrest at G2/M phase, while downregulation the mRNA expression of Cyclin D1 following incubation for $24 \mathrm{~h}$. Furthermore, the present study revealed that PL inhibited the invasion of GC cells through suppressing the expression of MMP-9 and Twist, which are target genes of STAT3 relevant to cell invasion.

In conclusion, the present study was the first to reveal the inhibitory effects of PL on GC cells and to assess the underlying mechanisms. PL was demonstrated to inhibit the proliferation, cell cycle progression as well as invasion and migration of two GC cell lines. The underlying mechanisms were indicated to include the suppression of the JAK1,2/STAT3 signaling pathway as well as the inhibition of the expression of downstream genes. These results indicated that the consumption of long pepper is recommended for the prevention and treatment of GC, and that PL may represent a novel chemotherapeutic drug for GC.

\section{References}

1. Jemal A, Bray F, Center MM, Ferlay J, Ward E and Forman D: Global cancer statistics. CA Cancer J Clin 61: 69-90, 2011.

2. Lordick F, Allum W, Carneiro F, Mitry E, Tabernero J, Tan P, Van Cutsem E, van de Velde C and Cervantes A: Unmet needs and challenges in gastric cancer: The way forward. Cancer Treat Rev 40: 692-700, 2014.

3. SR A, Cervantes A and van de Velde CJ: Gastric cancer: Epidemiology, pathology and treatment. Ann Oncol 14 (Suppl 2): ii31-ii36, 2003

4. Falcone A: Future strategies and adjuvant treatment of gastric cancer. Ann Oncol 14 (Suppl 2): ii45-ii47, 2003.

5. Ang SD: Gastric cancer surgery: Can east meet west? J Surg Oncol 102: 736, 2010.

6. Krejs GJ: Gastric cancer: Epidemiology and risk factors. Dig Dis 28: 600-603, 2010.

7. Li W, Qin J, Sun YH and Liu TS: Neoadjuvant chemotherapy for advanced gastric cancer: A meta-analysis. World J Gastroenterol 16: 5621-5628, 2010.

8. Ahn HS, Lee HJ, Yoo MW, Jeong SH, Park DJ, Kim HH, Kim WH, Lee KU and Yang HK: Changes in clinicopathological features and survival after gastrectomy for gastric cancer over a 20-year period. Br J Surg 98: 255-260, 2011. 
9. Park BS, Son DJ, Park YH, Kim TW and Lee SE: Antiplatelet effects of acidamides isolated from the fruits of Piper longum L. Phytomedicine 14: 853-855, 2007.

10. Yang YC, Lee SG, Lee HK, Kim MK, Lee SH and Lee HS: A piperidine amide extracted from Piper longum L. fruit shows activity against Aedes aegypti mosquito larvae. J Agr Food Chem 50: 3765-3767, 2002

11. Son DJ, Kim SY, Han SS, Kim CW, Kumar S, Park BS, Lee SE, Yun YP, Jo H and Park YH: Piperlongumine inhibits atherosclerotic plaque formation and vascular smooth muscle cell proliferation by suppressing PDGF receptor signaling. Biochem Bioph Res Commun 427: 349-354, 2012.

12. Bang JS, Oh da H, Choi HM, Sur BJ, Lim SJ, Kim JY, Yang HI, Yoo MC, Hahm DH and Kim KS: Anti-inflammatory and antiarthritic effects of piperine in human interleukin 1beta-stimulated fibroblast-like synoviocytes and in rat arthritis models. Arthritis Res Ther 11: R49, 2009.

13. Fontenele JB, Leal L, Silveira ER, Felix FH, Bezerra Felipe CF and Viana GS: Antiplatelet effects of piplartine, an alkamide isolated from Piper tuberculatum: Possible involvement of cyclooxygenase blockade and antioxidant activity. J Pharm Pharmacol 61: 511-515, 2009.

14. Tsai IL, Lee FP, Wu CC, Duh CY, Ishikawa T, Chen JJ, Chen YC, Seki $\mathrm{H}$ and Chen IS: New cytotoxic cyclobutanoid amides, a new furanoid lignan and anti-platelet aggregation constituents from Piper arborescens. Planta Med 71: 535-542, 2005.

15. Wakade AS, Shah AS, Kulkarni MP and Juvekar AR: Protective effect of Piper longum L. on oxidative stress induced injury and cellular abnormality in adriamycin induced cardiotoxicity in rats. Indian J Exp Biol 46: 528-533, 2008.

16. Cícero Bezerra Felipe F and Trajano Sousa Filho J, de Oliveira Souza LE, Alexandre Silveira J, Esdras de Andrade Uchoa D, Rocha Silveira E, Deusdênia Loiola Pessoa O and de Barros Viana GS: Piplartine, an amide alkaloid from Piper tuberculatum, presents anxiolytic and antidepressant effects in mice. Phytomedicine 14: 605-612, 2007.

17. Vedhanayaki G, Shastri GV and Kuruvilla A: Analgesic activity of Piper longum Linn. root. Indian J Exp Biol 41: 649-651, 2003.

18. Randhawa H, Kibble $\mathrm{K}$, Zeng $\mathrm{H}$, Moyer $\mathrm{M}$ and Reindl $\mathrm{K}$ : Activation of ERK signaling and induction of colon cancer cel death by piperlongumine. Toxicol In Vitro 27: 1626-1633, 2013.

19. Dhillon H, Chikara S and Reindl KM: Piperlongumine induces pancreatic cancer cell death by enhancing reactive oxygen species and DNA damage. Toxicol Rep 1: 309-318, 2014.

20. Gong LH, Chen XX, Wang H, Jiang QW, Pan SS, Qiu JG, Mei XL, Xue YQ, Qin WM and Zheng FY: Piperlongumine induces apoptosis and synergizes with cisplatin or paclitaxel in human ovarian cancer cells. Oxid Med Cell Longev 2014: 906804, 2014

21. Livak KJ and Schmittgen TD: Analysis of relative gene expression data using real-time quantitative PCR and the 2(-Delta Delta C(T)) Method. Methods 25: 402-408, 2001.

22. Jackson C, Judd LM, Menheniott T, Kronborg I, Dow C, Yeomans ND, Boussioutas A, Robb L and Giraud A: Augmented gp130-mediated cytokine signalling accompanies human gastric cancer progression. J Pathol 213: 140-151, 2007.

23. Kanda N, Seno H, Konda Y, Marusawa H, Kanai M, Nakajima T, Kawashima T, Nanakin A, Sawabu T, Uenoyama Y, et al: STAT3 is constitutively activated and supports cell survival in association with survivin expression in gastric cancer cells. Oncogene 23 : 4921-4929, 2004.

24. Heinrich P, Behrmann I, Haan S, Hermanns HM, Müller-Newen G and Schaper F: Principles of interleukin (IL)-6-type cytokine signalling and its regulation. Biochem J 374: 1-20, 2003.
25. Böger C, Behrens HM and Röcken C: Ki67 - an unsuitable marker of gastric cancer prognosis unmasks intratumoral heterogeneity. J Surg Oncol 113: 46-54, 2016

26. Wang Y, Zhou X, Shan B, Han J, Wang F, Fan X, Lv Y, Chang L and Liu W: Downregulation of microRNA-33a promotes cyclin dependent kinase 6, cyclin D1 and PIM1 expression and gastric cancer cell proliferation. Mol Med Rep 12: 6491-6500, 2015.

27. Gao XH, Yang XQ, Wang BC, Liu SP and Wang FB Overexpression of twist and matrix metalloproteinase- 9 with metastasis and prognosis in gastric cancer. Asian Pac J Cancer Prev 14: 5055-5060, 2013.

28. Jatiani SS, Baker SJ, Silverman LR and Reddy EP: JAK/STAT pathways in cytokine signaling and myeloproliferative disorders: Approaches for targeted therapies. Genes Cancer 1: 979-993, 2010.

29. Wu H, Huang M, Cao P, Wang T, Shu Y and Liu P: MiR-135a targets JAK2 and inhibits gastric cancer cell proliferation. Cancer Biol Ther 13: 281-288, 2012.

30. Xiong H, Zhang ZG, Tian XQ, Sun DF, Liang QC, Zhang YJ, Lu R, Chen YX and Fang JY: Inhibition of JAK1,2/STAT3 signaling induces apoptosis, cell cycle arrest and reduces tumor cell invasion in colorectal cancer cells. Neoplasia 10: 287-297, 2008.

31. Ingley E and Klinken SP: Cross-regulation of JAK and Src kinases. Growth Factors 24: 89-95, 2006.

32. Akira S: Roles of STAT3 defined by tissue-specific gene targeting. Oncogene 19: 2607-2611, 2000.

33. Avalle L, Pensa S, Regis G, Novelli F and Poli V: STAT1 and STAT3 in tumorigenesis: A matter of balance. JAKSTAT 1: 65-72, 2012.

34. Chang Q, Bournazou E, Sansone P, Berishaj M, Gao SP, Daly L, Wels J, Theilen T, Granitto S, Zhang X, et al: The IL-6/JAK/Stat3 feed-forward loop drives tumorigenesis and metastasis. Neoplasia 15: 848-862, 2013.

35. Mukhopadhyay A1, Banerjee S, Stafford LJ, Xia C, Liu M and Aggarwal BB: Curcumin-induced suppression of cell proliferation correlates with down-regulation of cyclin D1 expression and CDK4-mediated retinoblastoma protein phosphorylation. Oncogene 21: 8852-8861, 2002.

36. Weinstein IB: Disorders in cell circuitry during multistage carcinogenesis: the role of homeostasis. Carcinogenesis 21: 857-864, 2000.

37. Yu LF, Zhu YB, Qiao MM, Zhong J, Tu SP and Wu YL: Constitutive activation and clinical significance of Stat 3 in human gastric cancer tissues and cell lines. Chin Med J 84: 2064-2069, 2004 (In Chinese).

38. Judd LM, Menheniott TR, Ling H, Jackson CB, Howlett M, Kalantzis A, Priebe $\mathrm{W}$ and Giraud AS: Inhibition of the JAK2/STAT3 pathway reduces gastric cancer growth in vitro and in vivo. PloS One 9: e95993, 2014.

39. Kim MJ, Nam HJ, Kim HP, Han SW, Im SA, Kim TY, Oh DY and Bang YJ: OPB-31121, a novel small molecular inhibitor, disrupts the JAK2/STAT3 pathway and exhibits an antitumor activity in gastric cancer cells. Cancer Lett 335: 145-152, 2013.

40. Khanna P, Chua PJ, Bay BH, Baeg GH: The JAK/STAT signaling cascade in gastric carcinoma (Review). Int J Oncol 47: 1617-1626, 2015.

41. Huang W, Yu LF, Zhong J, Wu W, Zhu JY, Jiang FX and Wu YL: Stat3 is involved in angiotensin II-induced expression of MMP2 in gastric cancer cells. Dig Dis Sci 54: 2056-2062, 2009.

42. Tactacan CM, Phua YW, Liu L, Zhang L, Humphrey ES Cowley M, Pinese M, Biankin AV and Daly RJ: The pseudokinase SgK223 promotes invasion of pancreatic ductal epithelial cells through JAK1/Stat3 signaling. Mol Cancer 14: 139-149, 2015. 